\title{
The Interstitial Status of Irish Gayness in Colm Tóibín's The Blackwater Lightship and The Master ${ }^{1}$
}

\author{
Jose M. Yebra \\ Centro Universitario de la Defensa (Zaragoza)
}

Copyright (c) 2014 by Jose M. Yebra. This text may be archived and redistributed both in electronic form and in hard copy, provided that the author and journal are properly cited and no fee is charged for access.

\begin{abstract}
This paper explores the liminal status of Irish gayness in the aftermath of its decriminalization in 1993. Colm Tóibín's The Blackwater Lightship (1999) tries to reconcile Irish Catholicism and traditional family with new models of Irishness. Declan, the protagonist of the novel, goes back home when he is about to die of AIDS. His return reveals a dysfunctional family which only his disease brings together. His grandmother, mother and sister mourn Declan's corpse-like body. Making reference to Julia Kristeva's concepts of "abjection" and "the chora" (1982, 1984), I contend that the hero's disease is a necessary sacrifice for the family and Ireland as a whole to resurface. The second part of the paper addresses Tóibín's The Master (2004), whose fictional Henry James counterbalances Declan's overt homosexuality and AIDS-related death. The Master delves into James's hybridity as a closeted American of Irish descent opposed to Oscar Wilde's flamboyant gay Irishness. The restraint of the former and the traumatic downfall of the latter make up the lateVictorian framework through which Declan's late-twentieth-century sacrifice becomes meaningful.
\end{abstract}

Key Words. Interstitiality, Irishness, gayness, AIDS, abjection, "chora".

Resumen. Este artículo analiza el estatus de liminalidad propio de la homosexualidad en Irlanda tras su descriminalización en 1993. La novela The Blackwater Lightship (1999) de Colm Tóibín intenta reconciliar la tradición católica y el concepto de familia de la tradición irlandesa con los nuevos paradigmas de la Irlanda actual. Declan, el protagonista de la novela, vuelve a casa a punto de morir de SIDA. Su vuelta desvela una familia disfuncional que solo su muerte parece poder recomponer. La abuela, madre y hermana de Declan lloran (sobre) su cuerpo moribundo. A través de conceptos como "abyección" y la "chora" de Julia Kristeva $(1982,1984)$, sostengo que la enfermedad del protagonista es un sacrificio necesario para que Irlanda y su concepción de familia sigan adelante. La segunda parte del artículo analiza The Master (2004), también de Tóibín. La versión ficcional de Henry James que protagoniza esta novela compensa la abierta homosexualidad de Declan y su muerte por SIDA. The Master explora el carácter híbrido de James, un homosexual (en el armario) norteamericano de origen irlandés, frente a la orgullosa sexualidad e identidad irlandesa de Oscar Wilde. El autocontrol del primero y la caída traumática del segundo constituyen el marco tardo-victoriano que da significado al sacrificio de Declan en el cambio de siglo.

Palabras clave

Lo intersticial, lo gay, lo irlandés, SIDA, abyección, "chora".

1. The research carried out for writing this article is part of a project financed by the Spanish Ministry of Economy and Competitiveness (MINECO) (code FFI2012-32719). The author is also grateful for the support of the Government of Aragón and the European Social Fund (ESF) (code H05).

ISSN 1699-311X 
The impact of AIDS on gay writing in the nineteen eighties and nineties is undeniable. At both sides of the Atlantic, British and American writers bore witness to the traumatic phenomenon which for some years threatened with erasing the gay community and its hardly gained culture. If gays had been persecuted for decades, simultaneously invisibilised and visibilised under the pressure of a schizophrenic heteronormativity, things could only worsen with the coming of AIDS. In the nineteen eighties, (diseased) gays had to be easily spotted to be blamed for their "sin" and be ostracized from society; yet, too much visibility was difficult to abide. While this was happening in Britain and the United States, Catholic Ireland was a priori an even more hostile territory. In Ireland, a character in Tóibín's The Blackwater Lightship (1999) points out, the problem 'did not exist' because "we don't talk about sex" (1999: 146). The pressure of tradition and an all-powerful church have made same-sex desire a taboo not to be mentioned among well-meaning Catholics. The Blackwater Lightship constitutes a reaction against -albeit from within- the Irish status quo.

In an interview with Tóibín, Angela Meyer points out and recalls the writer's outlook on the precarious condition of gayness in Ireland and (his) Irish writing:

In many interviews Tóibín does get asked about being an Irish writer, or a gay writer. I asked him how much he feels those aspects are integral to his work. 'Well, they're fundamental, but then the page is not a mirror. So you don't think about them.' Tóibín said, in some ways, ie. if you're a man or a woman, it has an effect on the way the world deals with you, but it isn't as though it's what you think of as you wake up in the morning. 'It mightn't effect how you deal with the page,' he said, 'if you're writing a sentence.' In a way it's the writer's job, according to Tóibín, 'to get involved in areas of self-suppression and self-annihilation ... whereby the page matters and you are the least burden on the page. But nonetheless, of course those things are important.' I mention, for example, how Kafka's context was important to the production of his work, it can't be left out (writing in German in Prague, Jewishness) but knowing the context isn't imperative to the reading of his work - it resonates through the internal states of his characters and the situations they navigate (2010).
As happens with Kafka, Tóibín's sociocultural context is not the key to understanding his texts. I do not intend to explore if/how his identity has made an influence on his writing. Yet, (homo)sexuality and Irishness will be addressed as fundamental concepts to understand his part in the literary tradition he belongs to. It is my main concern to analyse the interstitial discourse of gay Irishness in Tóibín's The Blackwater Lightship and The Master (2004). The former in particular is deeply embedded in Irish culture as it stands at the crossroads between the country (Catholic) tradition and its re-articulation. This hybridity is particularly precarious with the outburst of AIDS which, for many religious and political leaders, only confirmed the equation gayness $=$ punishment=disease $=$ death. The complex process of (dis)assimilation of sexual dissidence into Irish matriarchy in The Blackwater Lightship recalls The Testament of Mary (2012).

The Blackwater Lightship is set in rural Ireland where AIDS-victim Declan returns to die. After spending some years in Dublin as a liberated gay, he goes back home to spend his last months surrounded and nursed by the women of his family, namely his sister Helen, his mother Lily and his grandmother Dora. From the very beginning, the novel calls back the matrilineal tradition of Catholic Ireland. However, contrary to expectations, the relations between the generations of the women in the family are problematic, particularly since Lily's husband died years before. Only Declan's disease can bring them back together and thus restore family as a national good. The protagonist's gayness and gay-related disease prove to be decisive factors in Tóibín's rearticulation of bonds within and without the family, at both individual and community levels. Only in 1993 was gayness decriminalised in Ireland (Walshe 2008: 117). Published six years later, The Blackwater Lightship comes under the syndrome of a newly-gained modernity. Helen and Declan make up a new generation of Irish men and women who inhabit the liminal territory between the tradition in which they were brought up and the new values they represent. Dora and Lily also assume social changes despite moral and/or political discrepancies with the new system of values imported into the 
country. Declan's imminent death constitutes the catalyst of this process of social selfrevision and national transformation; as well as this, it is an excuse to portray the intergenerational clash in current Ireland and, more specifically, between mothers and daughters.

Although Declan returns to the females in the family for nurturance, it is his gay friends Paul and Larry who have actually cared for him until then. Meanwhile, the women try to understand each other and reconfigure their roles in the new Irish family and society. Thus, only Paul and Larry know how to deal with the disease because, as Helen finally realises, his brother "had replaced his family with his [gay] friends" (Tóibín 1999: 34). In the nineteen eighties and nineties AIDS victims -many of them gayshad to build up alternative families since their own were too scared or ashamed. This was particularly frequent in big cities like New York, San Francisco or London where the disease made its appearance early and spread very quickly: a whole web of nurturance, vindication and representation of gayness was therefore born. In Ireland all this process was delayed by the strength of classic family and Catholicism and the consequent repression of (homo)sexuality as a foreign phenomenon. Although Tóibín has worked and lived in New York, a deeply-rooted Irishness is still essential to his writing. Some of his heroes catalyse social change becoming martyrs in the process, though. Declan's disease and death, Oscar Wilde's trial for gross indecency, and Henry James's traumatophilia constitute redemptive forces for Ireland to overcome its atavism without it being fully rejected. Declan (and somehow the characters in The Master) fulfil a Messianic role that Irish culture allegedly needs to confront traumatic changes. Catholic sacrifice, pain, and suffering are here re-defined in the form of AIDS or gay ostracism. However, whereas most gay fiction in the USA and, to a lesser extent, in England reflected and helped build up an alternative social network for gay outcasts and AIDS victims, Tóibín's novels still resort to Irish socio-cultural structures, especially the family. Declan has hidden his sexual orientation and his disease from his family while in Dublin. Yet, once his death approaches, he returns to his homeland and family as if closing his vital circle. Irish tradition finally appropriates and narrates Declan's story, no matter how transgressive it has been until then.

The Blackwater Lightship and also (albeit tangentially) The Master deal with the problematic relation between sexual dissidence and Irish identity. The former attempts to recover the essentials of Irishness, namely its rural scenarios, its everyday life, its maritime landscapes (Tóibín 1999: 216, 239, 243, 260), which both limit the country within itself and open it to new lands, particularly America. The narrator's discourse is simple and truthful, yet full of symbolic references to the Irish land and sea (227). Although only Dora has remained in the rural county of Wexford, Lily, Helen and Declan eventually return there; they do so for the latter to die in contact with his origins and, more importantly, to recompose their dysfunctional family. It is as if no matter where the Irish travel and/or settle down, they cannot help returning to (the rural of) their mother island. Despite having many friends, Declan's grandmother says, he "has nobody of his own ... and that's why he came down here" (130).

Tóibín's recent novella The Testament of Mary (2012), a fictional monologue in which the Virgin apostrophizes her lifeless son, sheds new light on The Blackwater Lightship. Tóibín had already dealt with maternal-filial bonds in Mothers and Sons (2006) in Catholic Ireland. However, The Blackwater Lightship and The Testament of Mary infuse the topic with Messianic undertones; the former being a sort of secular prequel to the latter. Like Christ's death, that of Declan's pursues a redemptive teleology. Like the Virgin and Magdalene, the women around Declan cry his impending death. When he is about to die, in a symbolic turn, Dora kneels "down in front of him and holds his hands" (Tóibín 1999: 253). Both Declan and Christ die by proxy, for others and by others. They are pariahs in their respective societies, which they paradoxically fight and sacrifice for.

Critics like Eibhear Walshe have argued that Tóibín's coming-out as an Irish gay (writer) runs parallel to the changes in the country as a whole, particularly the way same-sex desire has "made its way out" (2008: 116). Whether Tóibín himself is an effect or a cause of 
changing times in Ireland does not concern this paper, which focuses on the problematic representation of gay eros and tanathos in contemporary Ireland in The Blackwater Lightship and The Master. Walshe insists on the feeling of unease Tóibín's novels transmit when tackling gay sexuality in post-decriminalization Ireland; a sense of unease which the critic attributes to "the limited range of narrative choices which are available for representations of the homoerotic" (2008: 117). However, the feeling of restlessness and anxiety transcends the gay question and, as Tóibín points out, spreads to Irishness as a whole. Both the gays and the Irish share a like for tragedy that Tóibín's writing cannot help conflating:

Gay writing has a tendency to deal with the tragic and the unfulfilled [whereas] Irish writing ... seems at its most content when there is a dead father or a dead child ... . The strongest images in Irish fiction, drama and poetry are brokenness, death, destruction. The plays are full of shouting, the poetry is full of elegy, the novels are full of funerals (Tóibín 2002: 25-26).

The Blackwater Lightship has a great deal of mother-daughter shouting, incomprehension and eventual reconciliation. Against the backcloth of the Irish Sea and Declan's impending death, the family becomes an allfemale territory. As happens in Catholic rituals it is the women who pray and cry the death of the protagonist male. They vicariously run the ritual and infuse it with a tragic tone. The male as body and spirit (be it Declan or Christ) remains the object of worship, desire and grief around which their lives turn. In fact, Dora assumes her (and gays') second-class status: "When real men are around, they [women] shut up and make tea" (1999: 212, my italics).

Unlike the over-explicit gay discourse of writers like Alan Hollinghurst, Tóibín's texts address sexuality as if from the corner of the eye. In The Blackwater Lightship Declan's body is devoid of sexual connotations, at least from a celebratory perspective. Only decay and death remain from the days when the hero enjoyed a post-decriminalization atmosphere of promiscuity in Dublin. In an advanced state of decomposition, his body is an interstitial territory between being and non-being, life and death, Irish tradition and foreign lifestyles. There is no single reference to (homo)sexual activity throughout the novel, except outside Ireland. Declan's friend Paul tells Helen about his consciousness-raising as a gay and his coming-out in Belgium (Tóibín 1999: 164). There he overtly fell in love with a French guy because, as he argues, there is a degree ofliberty in secular Europe unthinkable in the island. He recalls how Irish gays "were surprised at how they [French gays] shook hands with each other and kissed each other ... We did things in France that we didn't do in Ireland" $(163,167)$. Declan also participated of this fresh air and gay-friendly atmosphere in the continent. However, his diseased body must come back to Ireland as an allegory of sin and punishment. Declan's body can thus be read as the site of Irish Catholic morality and repression, as the casualty of the Irish modernization process. Like Christ, he is a victim born and dead for his people to (metaphorically) come to terms with the past and hence open up to the future. Despite the sexual undertones of AIDS, the novel focuses exclusively on Declan's last decaying moments. His body is no longer the recipient of desire and attraction, but of pain and abjection. This implicit link between same-sex desire, disease, death and religious and/or moral "punishment" (whether literally or ironically) is not exclusive to Irish culture. In this sense The Blackwater Lightship recalls texts like Jeanette Winterson's Written on the Body (1992) and Will Self's Dorian. An imitation (2002), but with a difference. It is indeed this unlike resemblance that makes the Irishness of Tóibín's novel particularly blatant. It also explains why this paper addresses non-Irish novels.

In Winterson's text the unnamed genderless narrator falls in love with beautiful Louise. Being the latter the victim of leukemia, she can only be cured by her husband, who happens to be an oncologist. It is then when the narrator self-exiles in a Yorkshire cottage as an ascetic. Like Tóibín's, Winterson's Christian background may explain this spiritual exile whereby the narrator tries to find his/her way to a redemptive grief. Once there s/he writes a lovepoem to Louise, which turns one of obsession 
with the body rotten by disease. The narrator's discourse enters Louise's body as the space of abjection; i.e. a space of repulsion and attachment. The poem almost physically dismembers the body: "Will your skin discolour its brightness blurring? Will your neck and spleen distend? Will the rigorous contours of your stomach swell under an infertile load?" (Winterson 1992: 125). Joan Smith points out how the narrator "metamorphoses into an embalmer" and addresses Louise "to hook out [her] brain through [her] accommodating orifices', to dissect [her] with 'a medical diagram and a cloth to mop up the mess, ... bagged neat and tidy" (1992). Winterson's novel delves into (and forms part of) feminist politics, especially the queer movement arising in the early nineties. Moreover, the clash between lesbian sexuality and Christian repressiveness and punishment (central to Oranges are not the Only Fruit, 1985) bolstered with the coming of AIDS. The disease scarcely affected the lesbian community. Yet the mutual interest and solidarity between female and male homosexuals increased when all forms of nonnormative sexuality were suspicious of social and moral destabilization. The poetics of disease and death resulting from this LBGT alliance helps approach novels like Written on the Body, The Blackwater Lightship and Dorian. An imitation. All of them explore the tension between eros and tanathos and question the representation of same-sex desire as the illicit, as a viral identity that willingly attacks society with disease and death. Self's Dorian, diseased with herpes and similar marks of abjection (2002: 177, 182), seems to enjoy infecting his lovers with AIDS: "Performing in excess of a thousand thousand HIV impregnations had given Dorian the forensic attitude of a virologist injecting an attenuated virus into experimental cohorts" (231). In History of Sexuality (1978), Michel Foucault explains the medicalization of non(hetero)normative bodies and practices as a Victorian discourse which is still valid today. Is therefore the abjection of lesbian and gay bodies in the novels by Winterson, Self and Tóibín the effect of their characters' introjection of these repressive discourses? In other words, are these texts the result of their characters' (internal) homophobia? Otherwise, how can their ghastly representation of dissident bodies and sexualities be read?

As mentioned above, the religious substratum in both Winterson and Tóibín's texts explains their novels' portrayal of bodies as (excessively) sexualized and, therefore, diseased in Christian/Catholic terms. Bodies become uncanny viral spaces which attract, threaten and horrify victims and witnesses alike. They are the abject Other that the narrator in Written on the Body and the hero's family and friends in The Blackwater Lightship must confront with. For Julia Kristeva, the abject:

$$
\begin{aligned}
& \text { has only one quality of the object - that of being } \\
& \text { opposed to I. If the object, however, through its } \\
& \text { opposition, settles me within the fragile texture } \\
& \text { of a desire for meaning, which, as a matter of } \\
& \text { fact, makes me ceaselessly and infinitely } \\
& \text { homologous to it, what is abject, on the contrary, } \\
& \text { the jettisoned object, is radically excluded and } \\
& \text { draws me toward the place where meaning } \\
& \text { collapses (1982: 1-2). }
\end{aligned}
$$

The most archaic form of abject dissociation between subject and object, self and other is food loathing (Kristeva 1982: 2), as well as "the open wound, shit, sewage" (in Felluga: 2011). Yet, what traumatically reminds us of our materiality is the corpse as a liminal signifier:

These body fluids, this defilement, this shit are what life withstands, hardly and with difficulty, on the part of death. There, I am at the border of my condition as a living being. My body extricates itself, as being alive, from that border. Such wastes drop so that I might live, until, from loss to loss, nothing remains in me and my entire body falls beyond the limit - cadere, cadaver (Kristeva 1982: 3).

Although still alive, Louise, Dorian and Declan are virtually corpses that compel readers, characters and themselves to revise the very essence of materiality in its most horrifying fashion. The narrators seem to lap up with gory details. However, the excess of filthy corporeality is not gratuitous. The abject is here an aesthetic and political statement. Against the normative aesthetics of beauty, these novels opt 
for an aesthetics of excess. This responds to the search of new ways of (gay, lesbian and queer) representation. The breakdown in meaning between subject and object and self and other particularly affects (sexual) minorities, their liminal status and their erotic/identification cathexes. In other words, they desire and identify with their same (gender), which brings about an excess of sameness similar to that provoked by the confrontation with the abject. Declan's constant vomiting, diarrhoea (Tóibín1999: 221) and corpse-like appearance threaten the boundaries that separate and connect him/us to the Other. This furthers the hero's return (both physical and psychosexual) to his origins. He goes back to his homeland, his family and his mother through what Kristeva calls the chora.

The chora is the earliest stage of psychosexual development. It is a modality of pre-linguistic significance, "an essentially mobile and extremely provisional articulation constituted by movements and their ephemeral stases" (Kristeva 1984: 93). The chora is essentially liminal since "it precedes evidence, verisimilitude, spatiality and temporality" (94) and also because the subject cannot split from his/her mother or any other. S/he lives in the realm of the same, where (linguistic) boundaries do not hold: "A preverbal functional state that governs the connections between the body ... objects and the protagonists of the family structure" (95). Such a state is, according to Kristeva, dominated by contradictory drives, particularly eros and tanathos (in Bjelic 2011: 82-83). The choric scenario also recalls Nietzsche's Dionysian (in opposition to the Apollinean) and Freud's 'polymorphous perversity', namely the practices prior to normative (reproductive) heterosexuality. Declan's sexuality and disease are indefinable and 'perverse' because they threaten the (hetero)normative socio-cultural scenario the hero comes from. In other words, his transgressive death acts from within since it re-fashions the Catholic mother-son bond as represented by the Virgin Mary and Christ. Although Declan's lifestyle has set him apart from his mother Lily, the novel compels them to re-establish the original state of undifferentation or chora. By returning home, he comes back to the primal repression and prelinguistic stage. On the verge of death, Declan "was saying. 'Mammy, Mammy, help me, Mammy.' ... [his] tone when he spoke was abject, childlike, desperate as he called out again: "Mammy, Mammy, help me, Mammy." (Tóibín 1999: 258). AIDS is paradoxically a catalyst of this return to national/psychosexual origins in The Blackwater Lightship. The physical effects of the disease reenact the poetics of abjection which help us confront our unbearable physicality, desire, and life drive (eros) and death (tanathos) as a return to ourselves. Dora's house in rural Ireland, particularly the undifferentiated and aquatic immensity of the sea, constitute the scenario of Declan's return to the chora, his pre-existence as an individual, his oneness with his (m)others. When told to return to Dublin, Declan rejects to go (257) and stays at home instead. Nevertheless, he builds up a new (sexual) identity, which is different from the one traditional Irishness keeps for him. He is not meant to be a Catholic paterfamilias, though his grandmother's neighbours seem unable to understand it. When Declan is really ill, one of them says: "He'll never get a wife if he doesn't fatten up" (246). Despite such a repressive atmosphere and his overt gayness, in the end he only feels safe under the guidance and care of the females in his family.

Defying the oversexualization of current gay heroes, Declan's body is de-sexualised. Its monstrosity resonates with the abject atavism of the primordial bond with the mother. This is particularly so in (Tóibín's) rural Ireland, where the limits between official religion and patriarchy clash with an undermining matriarchy: "Abjection appears as a rite defilement and pollution in the paganism that accompanies societies with a dominant or surviving matrilinear character" (Kristeva 1982: 17). It is in this interstitial female Catholicism where Declan's sexual dissidence eventually deserves forgiveness and nurturance. The Blackwater Lightship seems to reject identifying abjection with the mother; she is no longer the monstrous body that threatens the Symbolic Order of the Father. Lily, we learn, has not been able to elicit a proper motherson/daughter bond. To an extent she and Dora 
apparently confirm the normative discourse on the maternal body as archaic and destabilizing. Our culture, Kristeva argues, relies on the repression of that maternal pre-Symbolic Order (1982: 101). However, Tóibín's novel eventually defies such a view. Women take centre stage whereas the traumatic effect of AIDS necessarily reconfigures the limits of representation. Dora, Lily and Helen learn to articulate their new roles and allegiances as the novel advances. The Blackwater Lightship even closes with a partial reconciliation between mother and daughter linking arms and walking together (1999: 245). Only the sacrifice of Declan's abject body can enact a promising future for the family. If our culture is based on horror and repression of the (m)other to confirm the primacy of the Symbolic, Tóibín's text constitutes a clever updating of that principle. The abject is displaced from the mother and the Ireland she represents to her diseased son. The females in the family mourn Declan's 'corpse', thus coming to terms with their own precariousness: "Awareness of the corpse confirms the fragility of identity, a disturbance of borders that threatens symbolic integrity with a return to the emptiness which preceded it and which is its destiny" (Newman, 1993: 139-140). The process of mourning in the novel answers to Kristeva's claim "that certain social and religious rituals function to displace abjection" (in Newman, 140). Thus, the women in the family exorcise themselves and Ireland through a rite of death and renewal. In this light, Helen goes to the sea in search of an annihilating sublime for comfort and healing. From the edge of a cliff, Declan's virus, the memories at her grandmother's and "the love for her family ... seemed like nothing" (Tóibín 1999: 260). Nothingness is paradoxically a metaphor of healing for Helen: "Imaginings and resonances and pain and small longings and prejudices. They meant nothing against the resolute hardness of the sea" (260).

Declan's messianic force in the name of a new Ireland contrasts with that of Henry James's fictional alter ego in Tóibín's 2004 novel The Master which apparently circumvents AIDS and Irishness. Declan is not made responsible for his disease and its spreading (as many gay men were in the 1980s and 1990s), but he is crucified for the sake of his family and his country. James however negates (his) Irish origins and sublimates his body and sexual desire. Despite being Irish on three sides (the fourth one being Scottish) he "was happy to claim some English blood" (Tóibín 2010: 4). He was an Anglophile who, in Tóibín's words, "suffered from neither his sister's passionate radicalism nor her atavism. Ireland represented for him a sort of wildness that was alien to his nature. His English friends, in general, were members of the ruling class to which Ireland presented itself as a headache" (2). The Master narrates James's visit to his ancestors' land in 1895, though focusing on the tiresome existence of the English rulers in the island. The writer is firstly the guest of the Lord Lieutenant at Dublin Castle. Tired of the boring life at the castle, James moves to the Wolseleys', Lord Wolseley being the Commander of the Forces in Ireland. Tóibín resorts to James's diaries and letters for an accurate documentation of the writer's Irish experience, especially his disgust at the country's beggary and filth (2010: 10-11). Unlike Declan and Helen, who return to rural Ireland and to their mother, James feels estranged from his ancestors' homeland: "This journey now reminded him of travelling across the country, witnessing a squalor both abject and omnipresent" (Tóibín 2004: 26). Whereas The Blackwater Lightship indulges in the effects of AIDS (particularly on the articulation of gay Irishness as a liminal phenomenon in a new Ireland), Tóibín's James attempts to keep abjection at bay by focusing on beauty and art. Despite James's anglophilia -he became an English citizen in 1915- and contempt for the "alienated isle" -as he called Ireland- James's hero is still an "intruder" in Victorian England, just like Declan is in his own country and family. Their liminal status links the characters with each other and with Oscar Wilde, James's nemesis in The Master.

As The Master recalls, whereas James's Guy Domville was failing in its première, he made his way to a nearby theatre where Wilde's $A n$ Ideal Husband was being a big success. Tóibín himself points out that the rivalry between both writers in these months "offered a drama that any novelist would work with" (2010: 29). The 
contrasting trajectory of James and Wilde, as the two sides of the same coin, is aesthetically challenging. They had a lot in common since they were "very much inhabitants, and products, of the same milieu" (Anon. 2010). Their nationality and alleged sexual orientation explain their Otherness in late-Victorian London. James's dislike (even horror) of his rival "arose not only from Wilde's success as a playwright ... but from Wilde's flaunting on his sexuality and, indeed, of his Irishness" (Tóibín 2010: 21). Wilde was, much to James's regret, his Dorian Gray, the symptom of his own interstitial status. In an interview, Tóibín states the quasi-poetic opposition between both men (O'Toole 2008: 197); Wilde's excessive camp contrasts with "James's fearful self, both in relation to his Irishness and in relation to his sexuality quite early in the book" (205). Unlike many intellectuals, James did not sign a petition for Wilde's release after the trial against the marquis of Queensberry. James feared Wilde's flamboyancy, which threatened his fragile status of celebrity by proxy. Excess implies exposure and James only wanted his 'true' nature to remain a secret, as happened with the heroes of his novels. However, the hero of The Master does not eventually regard Wilde as an enemy and disapproves (though he feels irrepressibly enthralled by) his martyrdom:

The story of Wilde filled Henry's days now. He read whatever came into print about the case and waited for news. He wrote to William about the trial, making clear that he had no respect for Wilde, he disliked both his work and his activities on the stage of London society. Wilde, he insisted, had never been interesting to him, but now, as Wilde threw caution away and seemed ready to make himself into a public martyr, the Irish playwright began to interest him enormously (Tóibín 2004: 72-73).

Like Declan in The Blackwater Lightship, Tóibín's James goes through a traumatic process. However, he is not the Irish martyr Wilde was, not even the messianic one Declan is for the sake of his people. James is a silent sufferer; one inhabiting the liminal territory between both sides of the Atlantic, success and failure, social privilege and the horror at being exposed as the Other.

If The Blackwater Lightship responds, among other things, to the decriminalization of gayness in Ireland and the outburst of AIDS, the presence of Wilde in The Master is partly inspired by the cases of pederasty among the Irish clergy. As Tóibín confesses, these events played an active role in the writing of the novel (2008: 199) and vice versa. The scandals involving Irish priests recall the interest of tabloids in Wilde's trial one century before. Being defamed by Lord Queensberry, the writer brought the aristocrat to court. However, the whole episode turned upside down when Queensberry sued Wilde for corrupting his son Lord Alfred Douglas. Wilde thus turned from prosecutor to prosecuted. He justified his relationship with Douglas as part of a homoerotic tradition starting in ancient Greece. The judges did not acknowledge Wilde's claims though and he was eventually found guilty: same-sex desire was no longer a respectable masculine bond inter pares. Its practitioner was from then on a feminized male who identified with women and desired men. This is how homosexuality (and heterosexuality) was born as a species (Foucault 1978: 43) in the person of Oscar Wilde. Tóibín's James and Wilde as well as Declan are granted an identity through AIDS, sexual dissidence and Irishness.

Wilde's (sexual) dissidence is well known. Likewise, Declan is said to have spent "the time of his life" (Tóibín 1999: 182) as a liberated gay in London. The status of the fictional James is however more ambiguous. Being American by birth (but of Irish descent) and never an outspoken homosexual, he is a traumatophilic character (Yebra 2013: 49-52) unable to articulate his own desire and identity: "James's concealment of his Irishness and homosexuality was done by creating compartments whereby things were known to some and not to others. In his greatest novels, there is always a secret which, if disclosed, will be explosive" (Tóibín 2002b: 104). Such inarticulacy is evident in The Master's account of his bond with Constance Fenimore Woolson and his homoerotic encounters with young males. Tóibín's James refuses selfcompromising intimacy with his female friends for unexplained reasons. His attitude with young males is slightly different, though he 
also avoids being decoded. He wants to remain closeted in his liminal territory, Irish-American and sexually ambiguous, as his first encounter with young Hammond proves.

At the beginning of the novel Tóibín's James meets Hammond, an attractive corporal Lady Wolseley hires as Henry's footman during his visit to Dublin. Lady Wolseley's choice is not casual, but a gesture to her friend and the readers. It is as if she was testing James's sexual orientation; "she studied him" (Tóibín 2004: 28), the narrator points out. Addressing James, she says about the soldier: "He has great charm, does he not, and discretion, I think? ... He's looking after you and nobody else, and, of course, available all the time. ... Hammond said 'I will do everything to make him happy during his stay'. ... And I think he meant it" (28-29). When James is about to leave the castle, Lady Wolseley cannot help asking him about her choice: "And Hammond? Will you miss him?" (42). Why should James miss a servant? Why should the latter be discreet, available, and personally interested in making the master happy? and, if so, how? Her words are scattered with homoerotic hints about/at James that the interaction between the two men both confirms and denies. When the writer is left alone with the servant, sexual innuendos and bodily and emotional restraint start off. Like Lady Wolseley before, Hammond scrutinizes the writer, "examining him with an intensity which was almost unmannerly" (35). The corporal's interest in James is mute, uncanny, a semiotic game which may induce the casual spectator to think that "something momentous had occurred between them, that their silence had merely arisen because so much had been said" (36). The homoerotic undertones between both men explain "Hammond's face ... of mild concern" (39). Despite their different status, they share a code for the illicit. More than their restrained interest in each other, what brings the two men together is their liminality. "It's funny", Hammond points out, the Wolseleys' castle is "half Ireland and half England, like myself" (31). In short, both inhabit an interstitial territory geographically and metaphorically. They live on the edge, just like Wilde and Declan.

\section{Concluding Remarks}

José Carregal-Romero points out that The Blackwater Lightship "refuses to conform to traditional convention and arbitrary judgments and offers instead the opposite; a homosexual couple which does fulfil the moral and spiritual values often attached specifically to heterosexual marriage and parenthood" (2012: 6). Being true that Paul and Larry provide Declan with a supporting home during his coming-out and most of his disease, the hero of Tóibín's novel eventually returns to his family. Gays may make very good partners or surrogate parents with each other; yet, in the aftermath of AIDS, Tóibín's novel looks for a reconciliatory poetics of Irish tradition and new sexualities in the figure of Declan. The rural Ireland where he was born and his grandmother, mother and sister live is still stuck in the past. And although they welcome him back in the family, Declan only returns when he has gone through most of the disease with the help of his Other family. By then his body is rotten by AIDS; an aesthetics of abjection The Blackwater Lightship exploits to destabilise conventional Apollonian beauty and foster gay/queer political premises. In other words, writers like Tóibín further disgust to affect and "move" the reader away from historical homophobia through queer politics.

Despite its down-to-earth portrayal of a dysfunctional family, The Blackwater Lightship has mythic undertones. Declan's death is the final stage of a problematic Bildungsroman. His death, as explained in the paper, is sacrificial. He is not dying for his own sake, but for his/the family to remain a referent in a new Ireland. He thus becomes a necessary martyr for his country's gay community to be 'redeemed' in Catholic terms. Declan's martyrdom recalls those of Oscar Wilde and Henry James's in late-nineteenth-century England and their fictional counterparts in The Master. Wilde has become the symbol of Irish (sexual) transgression, but also of its traumatic repression: his excessive sexuality, Irish nationalism and success were eventually repressed by the late-Victorian system. Meanwhile, formerly canonical James has been lately exposed as a traumatised self-repressed 
gay character. Despite their differences, both represent the hybrid status of Irish gayness. As such they go through sacrificial rituals, being simultaneously pariahs, dissidents and eventually guides of their peoples. They are, both in reality and fiction, transitory figures whose death refurbishes old Ireland into a new one.

This process of renewal revolves around the (gay) male body as a site of attraction and abjection. This is particularly obvious in The Blackwater Lightship where AIDS becomes a metaphor of pain, change and return. Declan's body is abject with disease marks. Likewise, his Bildungsroman is mostly a return to the chora -both to his mother and home- as well as a way to move readers' affects and conscience.
The Master addresses AIDS vicariously. In fact, male bodies (like Hammond's) are unscathed by signs of the disease. However, returning to the fin de siècle in the era of AIDS does not inevitably imply a lack of compromise. It rather constitutes an aesthetic and political gesture which extends the disease outside its historical context. The discourse of sublimation in The Master is not necessarily less effective than that of abjection in The Blackwater Lightship. Both texts use valid strategies to cope with the interstitial status of gayness in today's Ireland. The death or suffering of Tóibín's martyrs fosters the redemptive process whereby the country reengages with its tradition from a brand new perspective.

\section{Works Cited}

Anon. 2010. "Wilde and James: Garlanded Rivalries, Guarded Shock”. http://www.poetrybookshoponline.com/ poetry_portal/wilde_and_james_garlanded_rivalries_guarded_sock. [retrieved 17/07/2013].

Bjelic, Duan. 2011. Normalising the Balkans. Farnham: Ashgate.

Carregal-Romero, José. 2012. "Colm Tóibín and Post-Nationalist Ireland: Redefining Family Through Alterity". Estudios Irlandeses, Number 7. 1-9

Felluga, Dino. 2011. "Modules on Kristeva: On Psychosexual Development". Introductory Guide to Critical Theory. Purdue University http://www.purdue. edu/guidetotheory/psychoanalysis/kristeva develop.html. [retrieved 29/09/2013].

Foucault, Michel. 1978. History of Sexuality. London: Vintage.

Kristeva, Julia. 1982. Powers of Horror. An Essay on Abjection. Trans. L. Roudiez. New York: Columbia UP. http://www.csus.edu/indiv/o/obriene/art206/readings/ kristeva\%20-\%20powers\%20of\%20horror[1].pdf [retrieved 17/08/2013].

1984. "Revolution in Poetic Language", in Moi, Toril (ed.). The Kristeva Reader. Trans. M. Waller. New York: Columbia UP: 89-136.

Meyer, Angela. 2010. "Exquisite restraint for maximum expression: an interview with Colm Tóibín" (part two) http://blogs.crikey.com.au/literaryminded/2010/07/04/ exquisite-restraint-for-maximum-expression-aninterview-with-colm-toibin-part-one/?wpmp_switcher=mobile [retrieved 22/07/2013]

Newman, Robert D. 1993. Transgressions of Reading. Duke UP.

O’Toole, Fintan. “An Interview with Colm Tóibín”, in Delaney, Paul (ed.). Reading Colm Tóibín. Dublin: The Liffey Press. 183-208.

Self, Will. 2002. Dorian. An Imitation. London: Penguin.

Smith, Joan. 1992. "Grazed anatomy: "Written On the Body", The Independent, 13 September. http://www.independent.co.uk/arts-entertainment/book-review--grazed-anatomy-written-on-the-bodyjeanette-winterson-cape-1399-1551195 .html [retrieved 12/09/2013]

Tóibín, Colm. 1999. The Blackwater Lightship. London: Picador. 2002. Love in Dark Time. Gay Lives from Wilde to Almodovar. London: Picador. 2002b. "Henry James and Ireland, A Footnote". The Dublin Review, 7 (Summer 2002). 96-113. 2004. The Master. London: Picador.

2010. All a Novelist Needs: Colm Tóibín on Henry James. Griffin, Susan M. (ed. and introd.). Baltimore: The Johns Hopkins University Press. 
. 2012. The Testament of Mary. Penguin: London.

Walshe, Eibhear. 2008 “'This particular Genie': The Elusive Gay Male Body in Tóibín's Novels”, in Delaney, Paul (ed.). Reading Colm Tóibín. Dublin: The Liffey Press. 115-130.

Winterson, Jeanette. 1996 (1985). Oranges are not the Only Fruit. London: Vintage. 1992. Written on the Body. London: Cape, Cop.

Yebra, José M. 2013. "Neo-Victorian Biofiction and Trauma Poetics in Colm Tóibín's The Master", NeoVictorian Studies (6.1.). http://www.neovictorian studies. com/41-74. [retrieved 12/10/2013]. 41-74.

Received $19^{\text {th }}$ November $2013 \quad$ Last version $1^{\text {st }}$ February 2014

José M. Yebra is a lecturer in English at the Centro Universitario de la Defensa, Zaragoza. He has published articles on postmodern British and Irish literature, particularly Alan Hollinghurst, Will Self and Colm Tóibín. His research interests include postmodernism, trauma and gender studies. 